Ann. Biol. anim. Bioch. Biophys., 1978, 18 (2 B), 427-434.

\title{
Prostaglandins in ovulation
}

\author{
by M. R. CLARK, Wilma F. TRIEBWASSER, J. M. MARSH, W. J. LEMAIRE \\ Departments of Obstetrics-Gynecology and Biochemistry, \\ The Endocrine Laboratory, University of Miami, School of Medicine \\ Miami, Florida 33152, U. S. A.
}

\begin{abstract}
Summary. Evidence accumulated using prostaglandin synthesis inhibitors, prostaglandin measurements, or prostaglandin antibodies in several species has supported the concept that a gonadotropin-induced preovulatory rise in follicular prostaglandins is required for ovulation. There are at least three questions which need to be answered for a further understanding of this requirement : 1) What is the mechanism by which gonadotropin can stimulate prostaglandin synthesis? 2) In which cell type(s) are prostaglandins produced, and upon which do they act ? 3) What are the actions of prostaglandins which participate in ovulation? There have been recent advances which partially answer the first two questions. Gonadotropins appear to stimulate prostaglandin synthesis by increasing the quantities of follicular cyclic AMP (or possibly cyclic GMP). Derivatives of both nucleotides have been found to be effective exogenously. The effect of gonadotropin on prostaglandin synthesis also exhibits a delay of several hours and requires macromolecular synthesis. As to the first portion of question two, it appears that granulosa cells produce the bulk of follicular prostaglandins. It is not clear at this time, however, which cell(s) respond to the preovulatory rise in follicular prostaglandins, nor precisely how that response relates to ovulation.
\end{abstract}

\section{Introduction.}

Considerable evidence exists supporting a role for prostaglandins in the process of ovulation in the rat and rabbit (LeMaire and Marsh, 1977). Inhibition of prostaglandin synthesis by the systemic or local administration of indomethacin or aspirin has been shown to block ovulation in the rabbit and the rat (Behrman and Caldwell, 1974 ; Zor and Lamprecht, 1977). Since this block could not be overcome by LH, but could be reversed by administration of exogenous prostaglandins, the prostaglandin involvement appeared to be at the ovarian level. Earlier, it had been shown that rabbit ovarian follicles undergo marked changes in prostaglandins around the time of ovulation (fig. 1 ; Armstrong et al., 1974 ; Bowring et al., 1975). Prostaglandins of the $F$ (PGF) and $E$ (PGE) series both increased in ovulated follicles, but not in follicles which failed to ovulate (fig. 1). These increases were not seen when indomethacin was administered systemically (Yang et al., 1973 ; Armstrong et al., 1974) or intrafollicularly (Armstrong et al., 1974). In addition, intrafollicular injection of a prostaglandin antibody prevented LH-induced ovulation only in the injected follicle (Armstrong et al., 
1974). Antiserum to PGF was more effective than that to PGE in these experiments in rabbits.
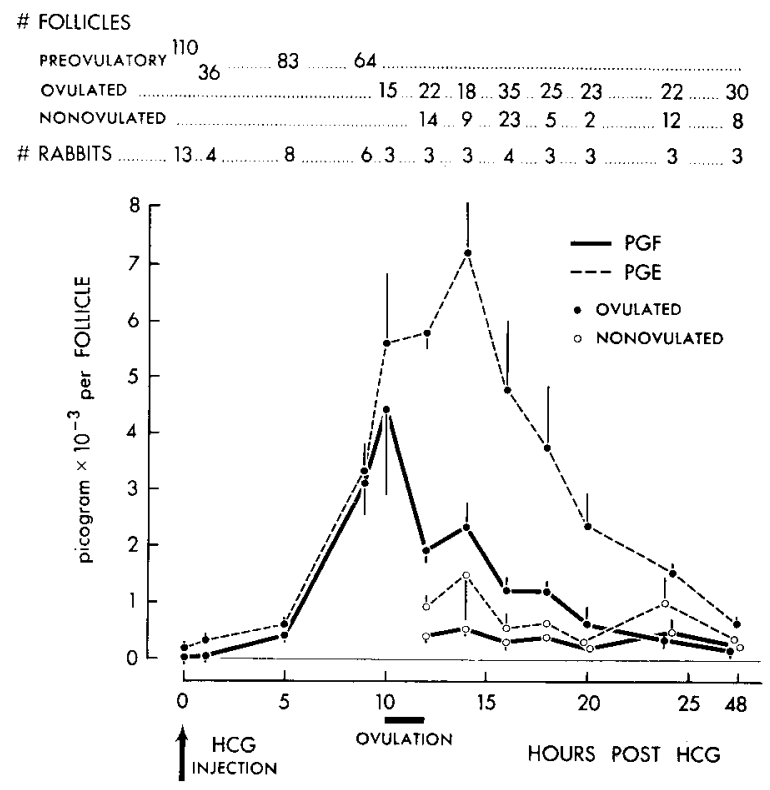

FIG. 1. - Pre- and postovulatory changes in prostaglandin levels in rabbit Graafian follicles. The ovulatory process was initiated by the intravenous injection of 100 i.u. of hCG. At 5 and $9 \mathrm{hr}$ the large preovulatory follicles were dissected and radioimmunoassay of follicular PGE and PGF carried out. At $10 \mathrm{hr}$ and later the follicles that had ovulated by morphological criteria were measured as the group of ovulated follicles. From $12 \mathrm{hr}$ onward, the large follicles which did not show evidence of ovulation were also dissected and grouped as nonovulated follicles. The number of each type of follicle analyzed and the number of animals at each time are indicated at the top of the figure. The points represent the mean, and the brackets the standard error of the mean. When no brackets are shown, the point represents the average of only two determinations (From Yang ef al., 1974).

A similar increase in prostaglandins in preovulatory follicles has also been observed in adult rats (LeMaire ef al., 1975 ; Bauminger and Lindner, 1975) and in immature rats treated with PMSG (Armstrong ef al., 1974 ; lesaka ef al., 1975). Prostaglandins increased after either an endogenous surge of $\mathrm{LH}$ or administration of gonadotropin.

Although not as extensively studied as the rat and rabbit, there is some evidence that prostaglandins are involved in ovulation in many other species. Inhibition of prostaglandin synthesis blocked ovulation in the goldfish, mouse, and monkey (LeMaire and Marsh, 1977). Preovulatory increases in prostaglandins have been reported in swine (Ainsworth et al., 1975). Stimulation of ovarian prostaglandin synthesis by LH in vitro has been observed for follicular tissue from bovine (Shemesh and Hansel, 1975) and human (Plunkett et al., 1975) origin.

Not all of the available data, however, supports a role for prostaglandins in ovulation. In at least one species, the chicken, administration of indomethacin (in a dose sufficient to significantly inhibit PGF levels in preovulatory follicles) failed to 
block ovulation (Day and Nalbandov, 1977). The administration of aspirin to women (Chaudhuri and Elder, 1976) and active immunization against $\mathrm{PGE}_{2}$ and $\mathrm{PGF}_{2 \alpha}$ in rats (Bauminger, 1977) also failed to block ovulation, although it was not determined in these studies if in fact follicular prostaglandin increases were inhibited. With these possible exceptions, then, prostaglandins have been shown to have an important role in the process of ovulation.

\section{Current studies}

Following the earlier observations made in vivo, ceriain aspects of follicular prostaglandin synthesis were investigated in vitro by ourselves and others.

One such aspect was the role of cyclic AMP in LH stimulation of prostaglandin synthesis. Graafian follicles isolated from estrous rabbits and incubated for 5 hrs with LH $(5 \mu \mathrm{g} / \mathrm{ml})$ produced increased quantities of both PGE and PGF (Marsh et al., 1974). PGF synthesis in rabbit follicles was also stimulated by LH in an organ culture system (Moon et al., 1974). This effect was specific for LH and could not be elicited in rabbit follicles by FSH, prolactin, or BSA (Marsh ef al., 1974). The addition of cyclic AMP (CAMP), however, could mimic the action of LH (fig. 2).

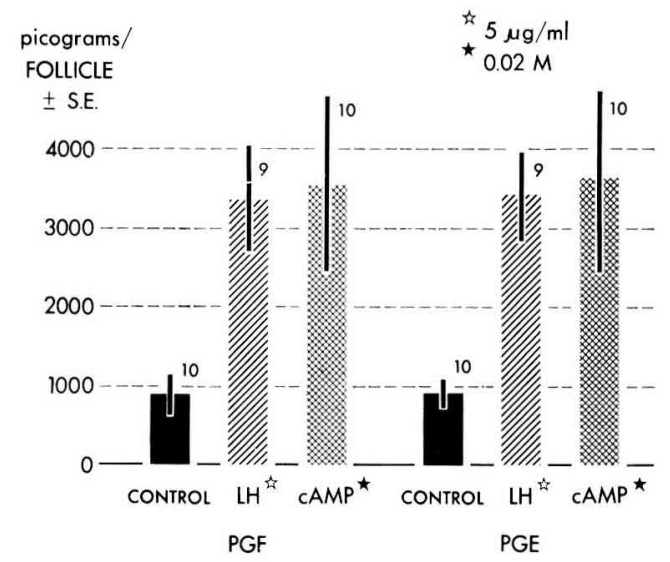

FIG. 2. - Prosiaglandin synthesis in isolated rabbit Graafian follicles incubated in vitro: the effect of $L H$ and cyclic AMP. Follicles were isolated from the ovaries of estrous rabbits and incubated individually in buffer alone (control), or with the addition of LH or cyclic AMP (CAMP). Prostaglandins were measured by radioimmunoassay. The height of the bars represents the mean prostaglandin synthesis and the vertical lines depict the standard error of the mean. The numbers above the bars indicate the number of follicles in each group (From Marsh et al., 1974).

The mediation of LH stimulation of PGE synthesis by cyclic AMP was studied further with isolated rat Graafian follicles. It was found that ATP, ADP, 3'-AMP, 5'-AMP, and cyclic GMP were not capable of stimulating PGE synthesis, while cyclic AMP and 1-methyl-3-isobutylxanthine produced significant stimulations (Clark et al., 1978). Derivatives of cyclic AMP such as dbcAMP, N6-mbcAMP, and 8-BrcAMP, were also effective (Clark et al., 1978). In contrast, it has been reported that 8-BrcGMP can stimulate PGE production in rat follicles, although conclusive data on the effect of 
LH on follicular cyclic GMP is not available (Zor ef al., 1977). In addition, it has been shown that cholera toxin increases both CAMP and PGE in rat follicles (Clark et al., 1978).

Since cyclic AMP is also known to increase ovarian steroidogenesis, the possibility existed that the action of $\mathrm{LH}$ on prostaglandins was mediated by this effect on steroidogenesis (LeMaire and Marsh, 1975). This proposal was disproven by the finding that the inhibition of steroidogenesis by aminoglutethimide did not prevent the LH-induced rise in prostaglandins (Bauminger et al., 1975).

It should be noted that a time lag of $3 \mathrm{hrs}$ or more was observed in vivo (fig. 1 ; Bauminger and Lindner, 1975) and in vitro (Clark et al., 1976) between exposure of follicles to $\mathrm{LH}$ and detectable increases in prostaglandin synthesis. This lag did not appear to be due to a requirement of sufficient time for increased steroidogenesis to occur, as just discussed.

Since cyclic AMP could cause an increase in prostaglandins in rabbit follicles (Marsh ef al., 1974), it could be postulated that the time lag was due to a delay in production or action of cyclic AMP. There does not appear to be a time lag, however, in production of cyclic AMP by rat follicles (Nilsson ef al., 1974). Instead, the delay seems to be in the expression of the action of cyclic AMP, since exogenous cyclic AMP produced a delay similar to LH in incubated rat follicles (Clark et al., 1978). A similar lag was also observed in the stimulation of PGE production by 8 -Br-cyclic GMP in rat follicles (Zor et al., 1977).

The latent period, on the other hand, supported a requirement for macromolecular synthesis as a prerequisite to increased prostaglandin synthesis (Bauminger and Lindner, 1975). Such a requirement was found using isolated follicles from PMSG-treated immature rats as a model system. When Graafian follicles from these animals were incubated with LH, a marked increase in PGE synthesis was observed after $5 \mathrm{hrs}$ (fig. 3). This increase was blocked by simultaneous incubation with $10 \mu \mathrm{M}$

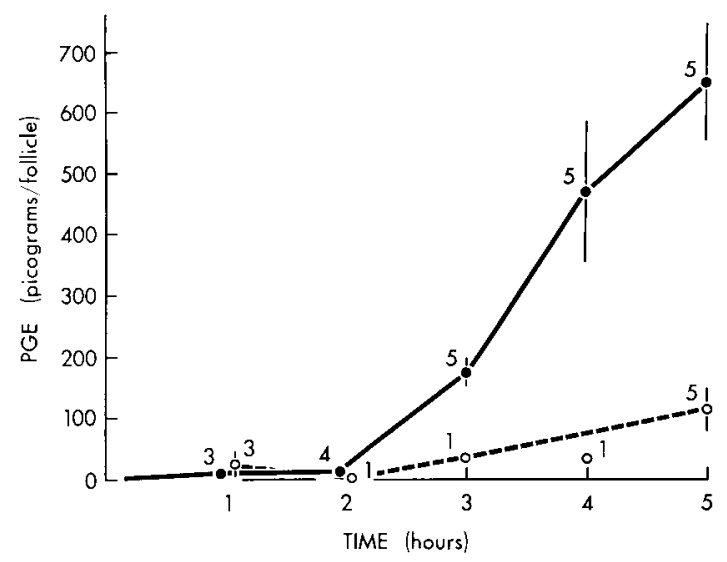

FIG. 3. - Time course of prostaglandin accumulation by rat follicles in vitro: effect of $L H$. Preovulatory follicles were isolated from PMSG-treated immature rats and preincubated for $1 \mathrm{hr}$. Groups of 3 follicles were then further incubated in fresh KRBB in the presence $(0-0)$ or absence $(0---0)$ of $5 \mu \mathrm{g} / \mathrm{ml}$ of LH (NIH-LH-S18). The total accumulation of PGE was measured by radioimmunoassay. The number of experiments appears adjacent to each point on the graph. Data are expressed as mean \pm standard error (From Clark ef al., 1976). 
puromycin, and not by $5 \mu \mathrm{M}$ puromycin aminonucleoside (Clark et al., 1976). Actinomycin $D(5 \mu \mathrm{M})$ and cycloheximide $(10 \mu \mathrm{M})$ were also capable of inhibiting the effect of LH (Clark, unpublished). The step in LH action requiring macromolecular synthesis appears to be beyond the production of cyclic nucleotides, since the effect of 8-BrcAMP (Clark, unpublished) and 8-BrcGMP (Zor et al., 1977) can also be blocked by cycloheximide. In this regard, an increase in follicular protein and RNA synthesis was found to precede ovulation and this increase was probably induced by the preovulatory gonadotropin surge (Mills, 1975). Furthermore, the direct intrafollicular injection of inhibitors of RNA and protein synthesis is capable of blocking ovulation in the rabbit (Pool and Lipner, 1966). The nature of the requirement for macromolecular synthesis, however, remains unknown.

For the further study of the role of prostaglandin synthesis in ovulation it is important to define which cell type(s) in the follicle produces prostaglandins. Current data suggest that granulosa cells are the source of prostaglandins. The separate culture of theca and granulosa cells from follicles of estrous rabbits for two days showed the majority of the PGF to be present in granulosa cells (Erickson ef al., 1977). PGE was not measured in this study. In our laboratory, however, it has been observed using acute $5 \mathrm{hr}$ incubation of separated components from preovulatory rabbit follicles, that the majority of the PGE is also produced by granulosa cells (Triebwasser, unpublished). It appears, therefore, that the granulosa cells are responsible for most or all of the production of PGE and PGF in the rabbit follicle. These findings allow the development of more definitive approaches to the regulation of prostaglandin synthesis by utilizing a single cell type.

\section{Model for the role of prostaglandins in ovulation}

Figure 4 attempts to summarize the position of prostaglandins in the scheme of events leading to ovulation (LeMaire ef al., 1977). It is not assumed that all of the events depicted occur in a single cell type, although many of them are capable of occuring in isolated granulosa cells. The ovulatory surge of $\mathrm{LH}$ initially acts upon a follicular cell by binding to its receptor, activating adenyl cyclase, and causing a rise in intracellular cyclic AMP. In the rat, FSH may also play some role in this process (LeMaire at al., 1977). The steps which follow the rise in cyclic AMP are only partially understood. They appear to involve protein kinase activation, protein synthesis, increased steroidogenesis, and prostaglandin synthesis. The manner in which prostaglandin accumulation is regulated could be by substrate availability, or by the amount of prostaglandin synthetase, or by changes in prostaglandin conversion to inactive metabolites. A clear choice between these alternatives cannot be made at this time (LeMaire et al., 1977).

The function of the preovulatory prostaglandin increase in the ovulatory process remains to be discovered. It has been suggested that follicular rupture involves an enzymatic weakening of the follicular wall (Bjersing, 1977), and prostaglandins might be involved in the activation, release, or synthesis of an ovulatory enzyme. Prostaglandins could also possibly act by influencing smooth muscle contraction, which has a proposed role in ovulation (Wallach et al., 1977). Recent observations, however, have not supported an effect of prostaglandins on contractility, since indome- 


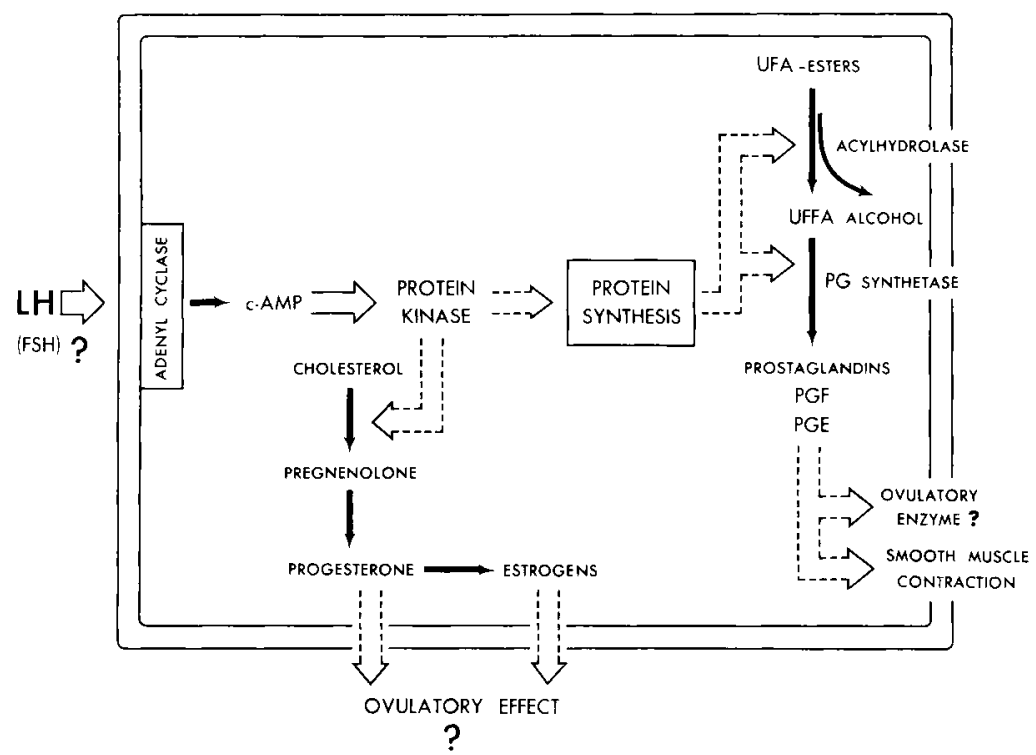

FIG. 4. - Hypothetical model of some aspects of the biochemical events in the ovulatory process. Abbreviations used are : $\mathrm{LH}=$ luteinizing hormone $; \mathrm{FSH}=$ follicle stimulating hormone ; $\mathrm{cAMP}=$ cyclic AMP ; UFA = unsaturated fatty acids ; UFFA = unsaturated free fatty acids ; alcohols = lysophospholipids, cholesterol and diglycerides. Solid arrows indicate biochemical conversions. The open and dashed arrows indicate stimulation. The dashed arrows imply possible, but yet unproven actions (From LeMaire et al., 1977).

thacin-induced reduction in ovulation in perfused rabbit ovaries was not accompanied by changes in ovarian contractility (Hamada ef al., 1977). The function of prostaglandins in ovulation, therefore, remains obscure and must await further definition of the process of ovulation on a morphological and biochemical basis.

$27 \mathrm{e}$ Congrès international des Sciences physiologiques, Symposium « Germ and somatic cell interaction 》 Paris, 21-23 juillet 1977.

Acknowledgements. - These studies were supported in part by NIH grants GM-5607, HD-03248, HD-05866, HD-08747-NIH Contract 2128, and the Ford Foundation Grant 0338. We thank Dr. J. Jewell, from the Ayerst Company for the gift of hCG, Dr. J. Pike from the Upjohn Company for the gift of prostaglandins, Dr. H. R. Behrman from Yale University for the gift of prostaglandin antibodies, Dr. Van Arman from the Merck Institute for the gift of indomethacin, and the National Institute of Arthritis and Metabolic Diseases for the gift of pituitary hormones. We thank Maria A. Rodriguez for her help in the preparation of this manuscript.

Résumé. Une augmentation préovulatoire des prostaglandines dans les follicules, induite par la gonadotropine, semble être nécessaire pour l'ovulation. Cette hypothèse s'appuie sur les résultats des études dans plusieurs espèces des prostaglandines dans les follicules, en employant des inhibiteurs de prostaglandines ou des anticorps contre les prostaglan- 
dines. Au moins trois questions demandent des études approfondies pour comprendre le rôle des prostaglandines : 1) Par quel mécanisme la gonadotropine est-elle capable de stimuler la synthèse des prostaglandines ? 2) Dans quel(s) type(s) de cellules les prostaglandines sont-elles synthétisées et sur quel(s) type(s) de cellules peuvent-elles agir ? 3) Quelles sont les actions des prostaglandines participant au mécanisme de l'ovulation?

Des résultats d'expériences récentes peuvent partiellement résoudre les deux premières questions. Notamment il a été démontré que la gonadotropine stimule la synthèse des prostaglandines par l'intermédiaire d'une augmentation de l'AMP cyclique dans les follicules (probablement aussi du GMP cyclique). C'est-à-dire que l'addition de dérivés de ces deux nucléotides est capable de stimuler la synthèse des prostaglandines dans les follicules isolés et incubés in vitro. Il a été également trouvé que l'action stimulante des gonadotropines sur la synthèse des prostaglandines se manifeste après un délai de plusieurs heures, nécessiłant la synthèse de macromolécules.

Finalement, les cellules de la granulosa semblent produire la majorité des prostaglandines folliculaires.

Quelles sont les cellules influencées par l'augmentation des prostaglandines et comment cette augmentation agit dans le mécanisme de l'ovulation restent actuellement presque complètement inconnus.

\section{References}

AINSWORTH L., BAKER R. D., ARMSTRONG D. T., 1975. Preovulatory changes in follicular fluid prostaglandin $\mathrm{F}$ levels in swine. Prostaglandins, 9, 915-925.

ARMSTRONG D. T., MOON Y. S., ZAMECNIK J., 1974. Evidence for a role of ovarian prostaglandin in ovulation, 345-363. In MOUDGAL N. R., Gonadotropins and gonadal function, Acad.Press, New York.

BAUMINGER S., LINDNER H. R., 1975. Periovulatory changes in ovarian prostaglandin formation and their hormonal control in the rat. Prostaglandins, 9, 737-751.

BAUMINGER S., LIEBERMAN M. E., LINDNER H. R., 1975. Steroid independent effect of gonadotropins on prostaglandin synthesis in rat Graafian follicles in vitro. Prostaglandins, 9, 753-764.

BAUMINGER S., 1977. Effect of active immunization with prostaglandin-protein conjugates on reproductive behaviour of female rats. 59th Annu. Meet. The Endocrine Society, New York, Abstr.81

BEHRMAN H. R., CALDWELL B. V., 1974. Role of prostaglandins in reproduction, 63-94. In GREEP R. O., Reproductive physiology, Vol. 8, Univ. Park Press, Baltimore.

BJERSING L., 1977 . In HAFEZ E. S. E., Human ovulation : mechanisms, detection and regulation. Elsevier/North Holland, Amsterdam (in press).

BOWRING N., EARTHLY M., MANGAN F. R., 1975. Changes in prostaglandin F content of the rabbit ovary associated with ovulation. J. Endocr., 64, 11P.

CHAUDHURI G., ELDER M. G., 1976. Lack of evidence for inhibition of ovulation by aspirin in women. Prostaglandins, 11, 727-735.

CLARK M. R., MARSH J. M., LeMAIRE, W. J., 1976. The role of protein synthesis in the stimulation by $\mathrm{LH}$ of prostaglandin accumulation in vitro. Prostaglandins, 12, 209-216.

CLARK M. R., MARSH J. M., LeMAIRE, W. J., 1978. Stimulation of prostaglandin accumulation in preovulatory rat follicles by adenosine 3', 5'-monophosphate. Endocrinology, 102, 39-44.

DAY S. L., NALBANDOV A. V., 1977. Presence of prostaglandin F (PGF) in hen follicles and its physiological role in ovulation and oviposition. Biol. Reprod., 16, 486-494.

ERICKSON G. F., CHALLIS J. R. G., RYAN K. J., 1977. Production of prostaglandin F by rabbit granulosa cells and thecal tissue. J. Reprod. Fert., 49, 133-134.

HAMADA Y., BRONSON R. A., WRIGHT K. H., WALLACH E. E., 1977. Ovulation in the perfused rabbit ovary : the influence of prostaglandins and prostaglandin inhibitors. Biol. Reprod., 17, 58-63.

IESAKA T., SATO T., IGARASHI M., 1975. Role of prostaglandin $F_{2 \alpha}$ in ovulation. Endocrinol. Japon., 22, 279-285.

LeMAIRE W. J., LEIDNER R., MARSH J. M., 1975. Pre-and postovulatory changes in the concentration of prostaglandins in rat Graafian follicles. Prosfaglandins, 9, 221-229. 
LeMAIRE W. J., MARSH J. M., 1977. Biochemical mechanism of ovulation In SCHOLLER R., Endocrinology of the ovary, Fresnes (in press).

LeMAIRE W. J., CLARK M. R., MARSH J. M., 1977. Biochemical mechanism of ovulation. In HAFEZ E. S. E., Human ovulation : mechanisms, detection and regulation. Elsevier/North Holland, Amsterdam (in press).

MARSH J. M., YANG N. S. T., LeMAIRE W. J., 1974. Prostaglandin synthesis in rabbit Graafian follicles in vitro. Effect of luteinizing hormone and cyclic AMP. Prostoglandins, 7, 269-283.

MILLS T. M., 1975. Protein and RNA synthesis in follicles isolated from rabbit ovaries. Proc. Soc. exp. Biol. Med., 148, 995-1000.

MOON Y. S., ZAMECNIK J., ARMSTRONG D. T., 1974. Stimulation of prostaglandin F synthesis by luteinizing hormone in rabbit ovarian follicles grown in organ culture. Life Sci. 15, $1731-1738$.

NILSSON L., ROSBERG S., AHREN K., 1974. Characteristics of the cyclic 3', 5'-AMP formation in isolated ovarian follicles from PMSG-treated immature rats after stimulation in vitro with gonadotropins and prostaglandins. Acta endocrinol., 77, 559-574.

PLUNKETT E. R., MOON Y. S., ZAMECNIK J., ARMSTRONG D. T., 1975. Preliminary evidence of a role for prostaglandin $F$ in human follicular function. Am. J. Obstet. Gynecol., 123, 391-397.

POOL W. R., LIPNER, H., 1966. Inhibition of ovulation by antibiotics. Endocrinology, 79, 858-864.

SHEMESH M., HANSEL W., 1975. Stimulation of prostaglandin synthesis in bovine ovarian tissue by arachidonic acid and luteinizing hormone. Biol. Reprod., 13, 448-452.

WALLACH E. E., WRIGHT K. H., OWMAN C., SJOBERG N. O., WALLES B., 1977. In HAFEZ E.S.E., Human ovulation : mechanisms, detection and regulation. Elsevier/North Holland, Amsterdam (in press).

YANG N. S. T., MARSH J. M., LeMAIRE W. J., 1973. Prostaglandin changes induced by ovulatory stimuli in rabbit Graafian follicles. The effect of indomethacin. Prostaglandins, 4, 395-404.

YANG N. S. T., MARSH J. M., LeMAIRE W. J., 1974. Postovulatory changes in the concentrations of prostaglandins in rabbit Graafian follicles. Prostaglandins, 6, 37-44.

ZOR U., LAMPRECHT S. A., 1977. Mechanism of prostaglandin action in endocrine glands. In LITWACK G., Biochemical actions of hormones, Vol. 4, Acad. Press, New York (in press).

ZOR U., STRULOVICI G., LINDNER H. R., 1977. Stimulation by cyclic GMP of prostaglandin E production in isolated Graafian follicles. Biochem. Biophys. Res. Commun., 76, 1086-1091. 